\title{
Nonfunctional Pelvic Retroperitoneal Para
Mimicking Postmenopausal Adnexal Mass
}

Zehra Kurdoglu', Mertihan Kurdoglu' ${ }^{1}$ E. Gulcin $A y^{1}$, Gulay Bulut ${ }^{2}$

\begin{abstract}
Paraganglioma is a rare tumor originates from paraganglial tissue which is composed of extraadrenal chromaffin cells. The pelvic and retroperitoneal location of this tumor is extremely rare and it can mimic adnexal mass. The diagnosis of paraganglioma in this region is difficult. The exact diagnosis may only be reached after the total excision and histopathologic examination of the tumor. In this report, for the first time, we presented a postmenopausal woman who had nonfunctional retroperitoneal paraganglioma mimicking postmenopausal adnexal mass. This case emphasizes that extraadrenal paraganglioma should be kept in mind in the differential diagnosis in all patients including postmenopausal woman with retroperitoneal mass even in the presence of nonspecific symptoms like abdominal pain.
\end{abstract}

Key words: Adnexal mass, paraganglioma, retroperitoneal area, menopause

\section{Postmenapozal Adneksiyal Kitleyi Taklit Eden Nonfonksiyonel Pelvik Retroperitoneal Paraganglioma ÖZET}

Paraganglioma, ekstraadrenal kromafin hücrelerinden oluşan paraganglial dokudan köken alan nadir bir tümördür. Tümörün pelvik ve retroperitoneal lokalizasyonu oldukça nadirdir ve adneksiyal kitleyi taklit edebilir. Bu bölgedeki paragangliomanın tanısı zordur. Kesin tanı, sadece total eksizyon ve tümörün histopatolojik incelemesi sonrasında konulabilir. Bu makalede, ilk kez, postmenopozal adneksiyal kitleyi taklit eden nonfonksiyonel retroperitoneal paragangliomalı postmenopozal kadın olguyu sunduk. Bu vakada vurgulanan; ekstraadrenal paragangliomanın karın ağrısı gibi spesifik olmayan semptom varlığında dahi postmenopozal retroperitoneal kadınlar da dahil olmak üzere her hastada ayırıcı tanıda akılda tutulması gerektiğidir.

Anahtar kelimeler: Adneksiyal kitle, paraganglioma, retroperitoneal bölge, menapoz

\section{INTRODUCTION}

Paragangliomas are extra-adrenal chromaffin tumors developing from neuroectodermal cells of the autonomic nervous system (1). It can develop anywhere that has paraganglial tissue which is composed of extraadrenal chromaffin cells, but the most frequent location is para-aortic region (2). Paragangliomas are $10-20 \%$ of the tumors which are associated with chromaffin tissue and $10 \%$ of these tumors are localized in the retroperitoneal region (3). Extraadrenal and non-functional forms are quite rare (1). They are usually asymptomatic and can reach significant sizes. Treatment of these tumors are usually surgical excision $(1,4)$. In this case, for the first

'Yuzuncu Yil University, Faculty of Medicine, Department of Obstetrics and Gynecology, Van, Turkey, ${ }^{2}$ Cardiovascular Training and Research Hospital, Department of Pathology, Van, Turkey.

Received: 14.07.2011, Accepted: 10.08.2011 time, a nonfunctional pelvic retroperitoneal paraganglioma mimicking postmenopausal adnexal mass was presented.

\section{CASE}

Sixty-year-old postmenopausal woman was referred to our clinic with the diagnosis of adnexal mass from the center which she had applied with abdominal pain. The patient who had been at menopause for 10 years had no complaints. Physical examination was normal. In her gynecological examination, a mass was palpated in the left adnexal area. On the transvaginal ultrasonography,

Correspondence: Zehra Kurdoglu, Assis. Prof. Dr., Yuzuncu Yil University, Faculty of Medicine, Department of Obstetrics and Gynecology, Kazım Karabekir Cad. Yüzüncü Yıl Üniversitesi Tıp Fakültesi Hastanesi, 65300, Van, Türkiye. Tel: 0432 2150471-6739 Fax: 04322157994 E-mail: zehrakurdoglu@hotmail.com 
the mass with solid and cystic components, $56 \mathrm{~mm}$ in diameter sized was detected on the left adnexal region. Uterus and right adnexal area were normal. Magnetic resonance imaging (MRI) showed a heterogeneous intensity $5.5 \times 4.5 \mathrm{~cm}$ sized mass on the left adnexal region. Tumor markers (CA 125, CEA, CA 15-3, CA 19-9, alpha fetoprotein and beta-HCG) were within normal limits. Exploratory laparotomy was performed and $5 \times 5.5 \mathrm{~cm}$ sized, mobile mass with well defined margins was palpated under the root of the sigmoid mesocolon. Uterus and both ovaries were normal. After entering the retroperitoneal space, the mass was removed totally by blunt and sharp dissection. Frozen section examination was reported as a neuroendocrine tumor and final histopathological examination revealed paraganglioma (Figure 1). On histopathological examination, neoplastic cells with vesicular nuclei and granular cytoplasm and with prominent nucleoli of some, together sustentacular cells were viewed under capsule. There was no mitotic activity. In the immunohistochemical examination, positive reaction was seen with synaptophysin and chromogranin A in neoplastic cells and with S-100 in sustentacular cells (Figure 2). Her blood and urine catecholamine levels were in normal limits. She was discharged on the postoperative fifth days but she did not apply to the hospital for control.

\section{DISCUSSION}

Retroperitoneal paragangliomas are rare tumors. Nonfunctional retroperitoneal types are very rare and often

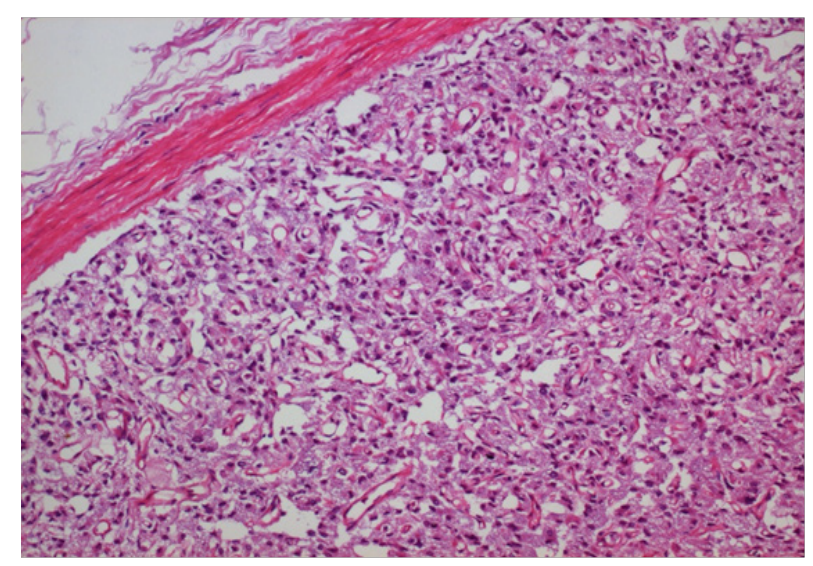

Figure 1. Marked with the capsule, paraganglioma of cells with granular cytoplasm (HE \& 200) isolated. The catecholamine levels in blood and urine should be normal to diagnose nonfunctional paraganglioma. Although these patients are usually ages of 40 (1), our patient was 60 years-old and she had been at menopause for 10 years and catecholamine levels were normal. These tumors are clinically latent. Non-specific symptoms such as the back and abdominal pain, urinary symptoms and general status changes can be found in the patients with paraganglioma (1). They are detected incidentally by imaging technique or are noted due to compression of adjacent organs. Tumor markers might be in normal range (5). Therefore, it is difficult to diagnose (6). Surgical resection is the most effective treatment for the paraganglioma (7). In our case, she had no symptoms except abdominal pain. A tumor could be noted after the gynecological examination especially transvaginal ultrasonography and MRI. On the exploration, there was no invasion seen. The tumor was isolated and it had well defined margins. It was removed carefully.

We searched Pubmed in June 2011 using the keywords "pelvic nonfunctional retroperitoneal paraganglioma" and "menopause" and found no article in the English literature. This is the first case who had nonfunctional retroperitoneal paraganglioma mimicking postmenopausal adnexal mass. Therefore, extraadrenal paraganglioma should be kept in mind in the differential diagnosis in all patients including postmenopausal woman with retroperitoneal mass even in the presence of nonspecific symptoms like abdominal pain.

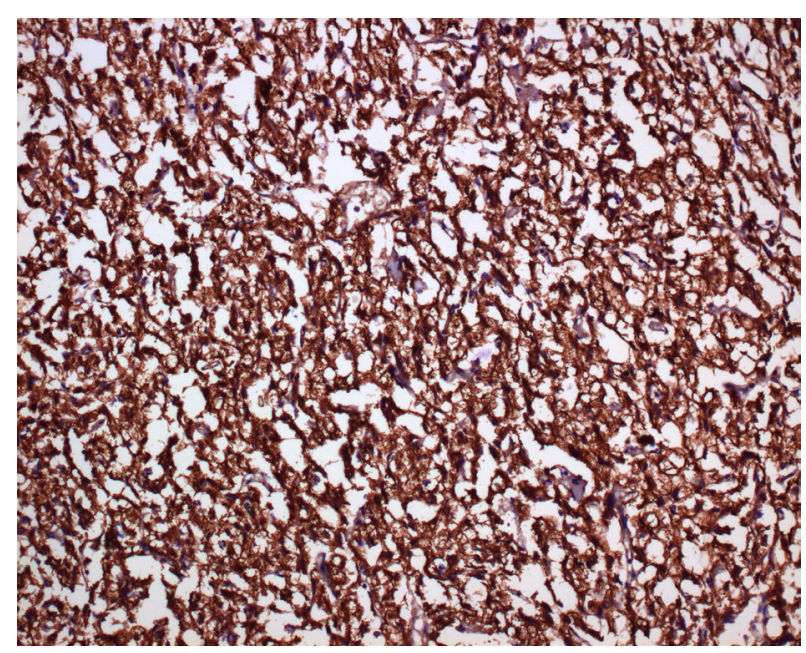

Figure 2. Tumor cells with positive staining of Chromogranin A (Chromogranin Ax200) 


\section{REFERENCES}

1. Hasbi S, El Khader A, El Fahssi M, et al. Retroperitoneal nonfunctioning paraganglioma. Can J Surg 2010; 53(1): E3-4.

2. Cunningham SC, Suh HS, Winter JM, Montgomery E, Schulick RD, Cameron JL, et al. Retroperitoneal paraganglioma: single-institution experience and review of the literature. J Gastrointest Surg 2006; 10(8): 1156-63.

3. Somasundar $P$, Krouse $R$, Hostetter $R$, Vaughan $R$, Covey $T$. Paragangliomas-a decade of clinical experince. J Surg Oncol 2000;74(4):286-90.
4. Whalen RK, Althausen AF, Daniels GH. Extraadrenal pheochromocytoma. J Urol 1992; 147(1): 1-10.

5. Kusçu E, Oktem M, Eroglu D, Haberal A, Bilezikci B, Demirhan B. Pelvic retroperitoneal paraganglioma mimicking an ovarian mass. Eur J Gynaecol Oncol 2005;26(2):219-20.

6. Ghidirim G, Rojnoveanu G, Mishin I, Gutsu E, lakovleva I. Extra-adrenal nonfunctional retroperitoneal paraganglioma: case report and review of the literature. Int Surg 2005; 90(5): 275-8.

7. Chang HC, Lin TC, Lin CM, Chuang FP, Sun GH, Cha TL, et al. Malignant Pelvic Paraganglioma with Bladder Invasion. J Med Sci 2010; 30(3):93-5. 